\title{
Water quality modeling to determine minimum instream flow for fish survival in tidal rivers
}

\author{
Wen-Cheng Liu ${ }^{\mathrm{a}}$, Shin-Yi Liu ${ }^{\mathrm{b}}$, Ming-Hsi Hsu ${ }^{\mathrm{b}} *$, Albert Y. Kuo ${ }^{\mathrm{c}}$ \\ ${ }^{a}$ Department of Civil and Disaster Prevention Engineering, National United University, Miao-Li 360, Taiwan, ROC \\ ${ }^{\mathrm{b}}$ Department of Bioenvironmental Systems Engineering and Hydrotech Research Institute, National Taiwan University, Taipei 10617, Taiwan, ROC \\ ${ }^{\mathrm{c}}$ National Center for Ocean Research, National Taiwan University, Taipei 10617, Taiwan, ROC
}

Received 4 April 2004; accepted 15 February 2005

\begin{abstract}
The Hsintien Stream is one of the major branches of the Danshuei River system, which runs through the metropolitan capital city of Taipei, Taiwan and receives a large amount of wastewater. The dissolved oxygen concentration is generally low in the tidal portion of the Hsintien Stream. Hypoxia/anoxia occurs often, particularly during the low-flow period when the Feitsui Reservoir, Chingtan Dam and Chihtan Dam impound the freshwater for municipal water supply. Fish kills happen from time to time.

This paper describes the application of a numerical hydrodynamic and water quality model to the Danshuei River system, with special attention to the tidal portion of the Hsintien Stream. The model is recalibrated with the prototype conditions of the year 2000. The hydrodynamic portion of the model is recalibrated with measured surface elevation and velocity at various stations in the river system. The water quality portion of the model is recalibrated with respect to the field data provided by Taiwan EPA. The input data of point and nonpoint sources are also estimated. The model simulates the concentrations of various forms of nutrients, CBOD and dissolved oxygen.

A series of sensitivity runs was conducted to investigate the effects of point source loadings and river flow on the DO level in the river. It is demonstrated that the augmentation of river flow has as much effect on raising DO level as the reduction of point source loadings. The completion of the Taipei sewer project is expected to reduce the point source loadings by at least $75 \%$. Under these reduced loadings, if the daily instream flow is maintained above the monthly $Q_{75}$ flow throughout the year, the minimum DO concentration in the river would not fall below $1 \mathrm{mg} / \mathrm{L}$, which is the suffocation level for most fish species in the Hsintien Stream. $\left(Q_{75}\right.$ is the flow which is equaled or exceeded $75 \%$ of the days in the month.) The Feitsui Reservoir, Chingtan Dam and Chihtan Dam may impound water during the high flow periods and release freshwater to maintain the flow at the $Q_{75}$ value in the Hsintien Stream during the drought periods.
\end{abstract}

(C) 2005 Elsevier Ltd. All rights reserved.

Keywords: Water quality simulation; Minimum instream flow; Model recalibration; Hsintien stream; Dissolved oxygen; Fish survival

\section{Introduction}

Minimum instream flows in rivers and streams aim to provide a certain level of protection for the aquatic environment. Various approaches have been used to gauge the level of stream protection; they include the maintenance of certain values of historical stream flows, streambed wetted perimeter and areas of suitable habitat. Although the legal right to divert stream water for off-site

\footnotetext{
* Corresponding author.

E-mail address: mhhsu@ntu.edu.tw (M.-H. Hsu).
}

0301-4797/\$ - see front matter (C) 2005 Elsevier Ltd. All rights reserved. doi:10.1016/j.jenvman.2005.02.005 uses has been recognized for centuries, the notion that instream flows are valuable and require protection is more recent (Lamb and Doerksem, 1987). This protection is based on the recognition that many private and public interests require that water flows within stream channels. These instream flows are typically needed for hydropower, navigation, fisheries, water treatment, recreation, and the maintenance of biodiversity. Regardless of the legal, environmental, or economic merit of establishing instream flows, the task of objectively determining what levels of flow are necessary to maintain a particular resource or ecosystem is a complex process (Lamb and Doerksen, 1987; Reiser et al., 1989; Beecher, 1990; King et al., 2001). In practice, minimum instream flow standards are usually based on some combination of the following: 
historic discharge, channel morphology, water quality, the ecology of aquatic species, empirical evidence, modeling, and ultimately arbitration between user groups. For a particular area, instream flow requirements will depend on local and downstream conditions and can vary considerably within areas of similar climate and hydrology (Beecher, 1990).

Recognition of the deleterious effects of river regulation on habitat provision for fish and invertebrates is now well documented (e.g. Petts, 1984; Hellawell, 1988; Harper and Ferguson, 1995). Numerous methods have been developed over the years to examine the impacts of flow changes on physical habitat (Lung et al., 1993; Jowett, 1997; Chau and Jin, 1998; Maddock, 1999). They vary from rapid reconnaissance level approaches that utilize hydrological indices to more complex approaches that combine detailed field measurements of instream habitat with the habitat requirements of selected target species. The most widely known and applied of these is the Physical Habitat Simulation System (PHABSIM) component of the Instream Flow Incremental Methodology (IFIM) (Bovee, 1995). However, the model is used to evaluate habitat requirements in the fluvial portion of a stream or river but is not applicable to the tidal river. There is no reference that can be found to determine the minimum instream flows in tidal estuaries.

Contamination generated from upstream development and human activity introduces a significant amount of nutrients into rivers and estuaries and, thus, accelerates the hypoxia or eutrophication process, spoils the public water resources, and requires costly remediation. Discharge of organic degradable materials into a flowing stream results in a decrease in dissolved oxygen concentration. This is apparent in low-flow periods when the assimilative capacity of the river decreases. The level of dissolved oxygen may fall below safety thresholds that are essential for the survival of aquatic species. To maintain dissolved oxygen above a given threshold, the assimilative capacity of the river should remain sufficient to cope with the pollutant load all along the river. This goal can be achieved by controlling the river flow rate and the wastewater pollutant load (Hayes et al., 1998; Hall and Chapman, 1985, Herbay, et al., 1983).

The objective of this study is to apply a numerical hydrodynamic and water quality model to the Danshuei River, Taiwan, with special attention to the tidal portion of the Hsintien Stream. Fish kill events have occurred in the Hsintien Stream in recent years. The Feitsui Reservoir, Chingtan Dam and Chihtan Dam are located upstream of the Hsintien Stream. These reservoir and dams impound freshwater for municipal water supply and control the river flow to affect the water quality in the Hsintien Stream. The water quality model is used to simulate the water quality condition in the Hsintien Stream, estimate the minimum instream flow for fish survival, and propose alternatives to improve the water quality.

\section{Model description}

\subsection{Governing equation}

Park and Kuo (1993, 1996) developed the HEM-2D model (two-dimensional Hydrodynamic Eutrophication Model) to simulate the water quality conditions in tidal rivers. The original version of the model is applicable only to a single stem tidal river. The model was later expanded to include the simulation of tributaries by Liu (1998) and applied to the Danshuei River system of Taiwan (Hsu et al., 1999).

The hydrodynamic model was developed on the foundation of the continuity equation, the momentum equation, and the mass-balance equation for salt. The water quality model is based on the laterally integrated equation describing the mass-balance of a dissolved or suspended substance in the water column

$$
\begin{aligned}
& \frac{\partial(C B)}{\partial t}+\frac{\partial(C B u)}{\partial x}+\frac{\partial(C B w)}{\partial z} \\
& =\frac{\partial}{\partial x}\left(K_{x} B \frac{\partial C}{\partial x}\right)+\frac{\partial}{\partial z}\left(K_{z} B \frac{\partial C}{\partial z}\right)+B S_{\mathrm{i}}+B S_{\mathrm{e}}
\end{aligned}
$$

where

$$
\begin{array}{ll}
t & \text { time }[\mathrm{T}] \\
x & \text { distance seaward along river axis }[\mathrm{L}] \\
z & \text { distance upward in the vertical direction }[\mathrm{L}] \\
B & \text { river width }[\mathrm{L}] \\
C & \begin{array}{l}
\text { laterally averaged concentration }\left[\mathrm{M} / \mathrm{L}^{3}\right] \\
\text { laterally averaged velocities in the } x \text { and } z \\
\text { directions, respectively }[\mathrm{L} / \mathrm{T}]
\end{array} \\
K_{x} \text { and } K_{z} \begin{array}{l}
\text { turbulent diffusion coefficients in the } x \text { and } z \\
\text { directions, respectively }\left[\mathrm{L}^{2} / \mathrm{T}\right]
\end{array} \\
S_{\mathrm{i}} & \begin{array}{l}
\text { time rate of internal increase (or decrease) by } \\
\text { biochemical reaction processes }\left[\mathrm{M} / \mathrm{L}^{3} \mathrm{~T}\right]
\end{array} \\
S_{\mathrm{e}} & \begin{array}{l}
\text { time rate of external addition (or withdrawal) } \\
\text { across the boundaries }\left[\mathrm{M} / \mathrm{L}^{3} \mathrm{~T}\right] .
\end{array}
\end{array}
$$

The water quality model consists of eight interlinked components including organic nitrogen $(\mathrm{ON})$, ammonium nitrogen $\left(\mathrm{NH}_{4}-\mathrm{N}\right)$, nitrite-nitrate nitrogen $\left(\mathrm{NO}_{2}+\mathrm{NO}_{3}-\mathrm{N}\right)$, organic phosphorus $(\mathrm{OP})$, inorganic phosphorus $\left(\mathrm{PO}_{4}-\mathrm{P}\right)$, chlorophyll ' $\mathrm{a}$ ' (chl), carbonaceous biochemical oxygen demand (CBOD), and the dissolved oxygen (DO). Each of the water quality components can be represented by the same equation as Eq. (1), but with its own representations of external $\left(S_{\mathrm{e}}\right)$ and internal $\left(S_{\mathrm{i}}\right)$ source and sink terms. Each rectangular box in Fig. 1 represents a component being simulated by the model. The arrows between components represent the biochemical transformation of one substance to the other. An arrow with one end unattached to a component (rectangular box) represents an internal source (or sink) due to the biochemical reaction or an external source (or sink). The detailed formulations of the various 


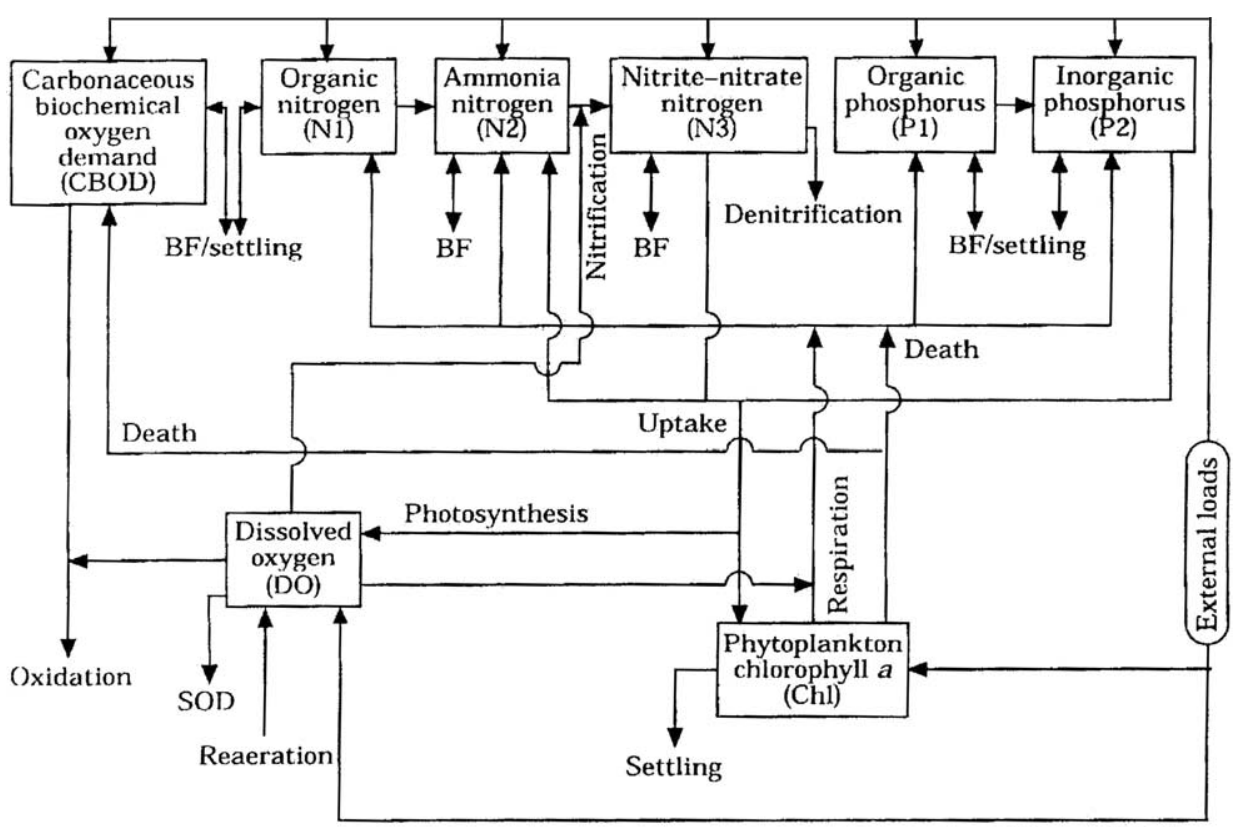

$\mathrm{BF}=$ benthic flux

Fig. 1. Schematic diagram of interacting water quality state variables.

water quality components together with types of sources/ sinks in the model can be found in Park and Kuo (1993) and Liu (1998).

The system of equations is solved using the finite difference method with a rectangular grid of spatially staggered variables. The geometry of the grid system used in the model and the locations of variables within the grid are shown in Fig. 2. In the grid system the surface elevation $\eta$ is defined at the middle of each segment, while $s, B, \rho, p$ and $C$ are at the center of the grid cell. The variables, $A_{z}, K_{z}$ and $w$ are defined at the bottom face of the grid cell, while $A_{x}, K_{x}$ and $u$ are defined at the center of the side wall. The variable $s$ is the laterally averaged salinity, $p$ is pressure, $\rho$ is water density, and $A_{x}$ and $A_{z}$ are the turbulent viscosities in the $x$ and $z$ directions, respectively.

In the numerical computation of the advection term, the central and upwind difference schemes, or a combination of the two, are routinely used. The upwind difference scheme introduces the artificial numerical diffusion and thus suffers from severe inaccuracies, although the numerical diffusion makes the scheme stable and guarantees nonnegative mass concentrations (Roache, 1972). The use of fine grid spacing can alleviate this problem, but the consideration of computational aspects, particularly in the longitudinal direction, makes it impractical for the modeling of two- or three-dimensional turbulent flows. On the other hand, the central difference scheme, which is high-order in accuracy and free of numerical diffusion, is nonconvergent particularly in regions where advection dominates over diffusion (Roache, 1972).

The unstable feature of a central difference scheme becomes more problematic in the mass-balance equation than in the momentum equation in which the sink term (friction) tends to dissipate this oscillatory behavior. Since the horizontal and vertical advection terms are relatively unimportant in the net momentum balance of the partially mixed estuaries (Pritchard, 1956), they are approximated with the central difference scheme.

The dominant salt balance, however, takes place between the horizontal advection and vertical turbulent diffusion (Pritchard, 1954), making the accurate numerical treatment of horizontal advection essential to the faithful behavior of the model. While the relatively small vertical advection term can be treated with the central difference scheme, the horizontal advective transport should be modeled with minimal introduction of artificial numerical oscillation or diffusion. The QUICKEST (quadratic upstream interpolation for convective kinematics with estimated streaming terms) scheme, which has been successfully adopted in the modeling of the advection term (Leonard et al., 1978; Hall and Chapman, 1985; Johnson et al., 1991), is used for

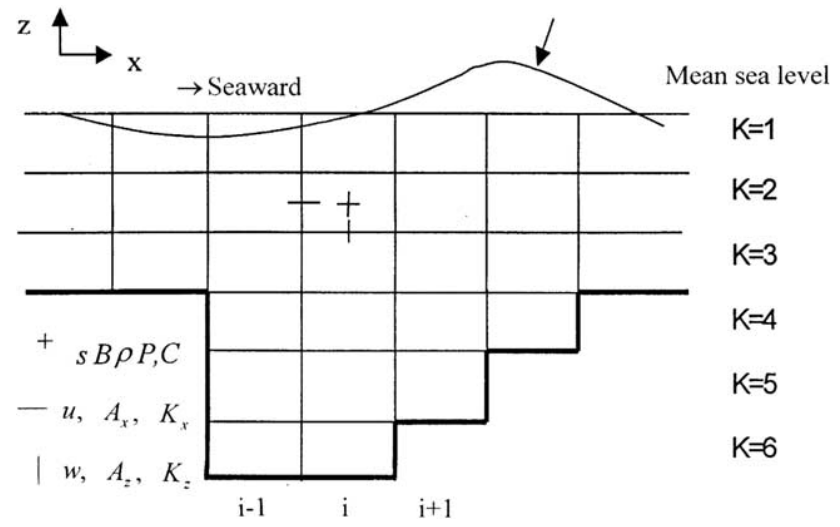

Fig. 2. Grid pattern, location and indexing of variables. 
the horizontal advection. The QUICKEST scheme is based on a conservative control volume formulation and estimates cell wall concentrations with a quadratic interpolation using concentrations in two adjacent cells and that at the next upstream cell. This method has the properties of high accuracy (third-order accurate in space) and significantly reduced numerical diffusion.

\subsection{Boundary conditions}

Boundary conditions need to be specified in the water quality model at four boundaries: the free surface, bottom, upstream and downstream boundaries. At the free surface, the wind-induced DO aeration is incorporated into the model using the equation developed by Banks and Herrera (1977). There is no other mass flux through the free surface. The mass fluxes at the bottom are specified specifically for each state variable by settling and benthic fluxes. The contributions of nonpoint source loadings from the upstream drainage area are specified as mass fluxes at the upstream boundary for each of the state variables.

The downstream boundary is located at the mouth of the estuary. The surface elevation is specified as a function of time either with harmonic functions or with time-series data measured at this boundary. In calculating velocities at the open boundary, the horizontal velocities are linearly extrapolated to a fictitious model transect outside the estuarine mouth, and the advective and diffusive terms are calculated over this fictitious model segment. An alternative approach is to assume that the dominant momentum balance takes place among the effects of surface slope, density gradient, and turbulent shear stress, neglecting the horizontal advection and diffusion of momentum at the mouth.
The difference between the results of the two methods is negligible, and the former method is adopted for this model.

Some 'oceanic' concentrations are assumed to exist off the mouth of the estuary. During flood tide, the oceanic water is advected into the estuary, changing the concentrations at the mouth until the oceanic concentrations are reached. Following the suggestion of Thatcher and Harleman (1972), a period of adjustment is allowed after the flow starts to flood and before the concentrations at the mouth reach the oceanic values. In this model, an input parameter is assigned for the specification of this adjustment period, and the concentrations are assumed to vary linearly with time during this period. During the ebb tide, the horizontal concentration profiles are assumed to be advected out of the mouth as a 'frozen' pattern.

\section{Study area}

The Danshuei River system (Fig. 3) is the largest estuarine system in Taiwan. It consists of three major tributaries: the Tahan Stream, Hsintien Stream and Keelung River. The Tahan and Hsintien Streams join at Wanhwa, Taipei city; afterwards, the estuarine system combines with the Keelung River at Kaundu, Taipei County. The river reach from Wanhwa to the river mouth is called the Danshuei River. The downstream portions of all three tributaries are influenced by tide, and subjected to seawater intrusion. Seawater, which can intrude into the upper estuary approximately $25 \mathrm{~km}$ from the river mouth, mixes well with the river water during flood tide, but mixing is only partial during ebb tide (Chang and Shih, 1991). Hsu et al. (1997) used the HEM-2D model to simulate

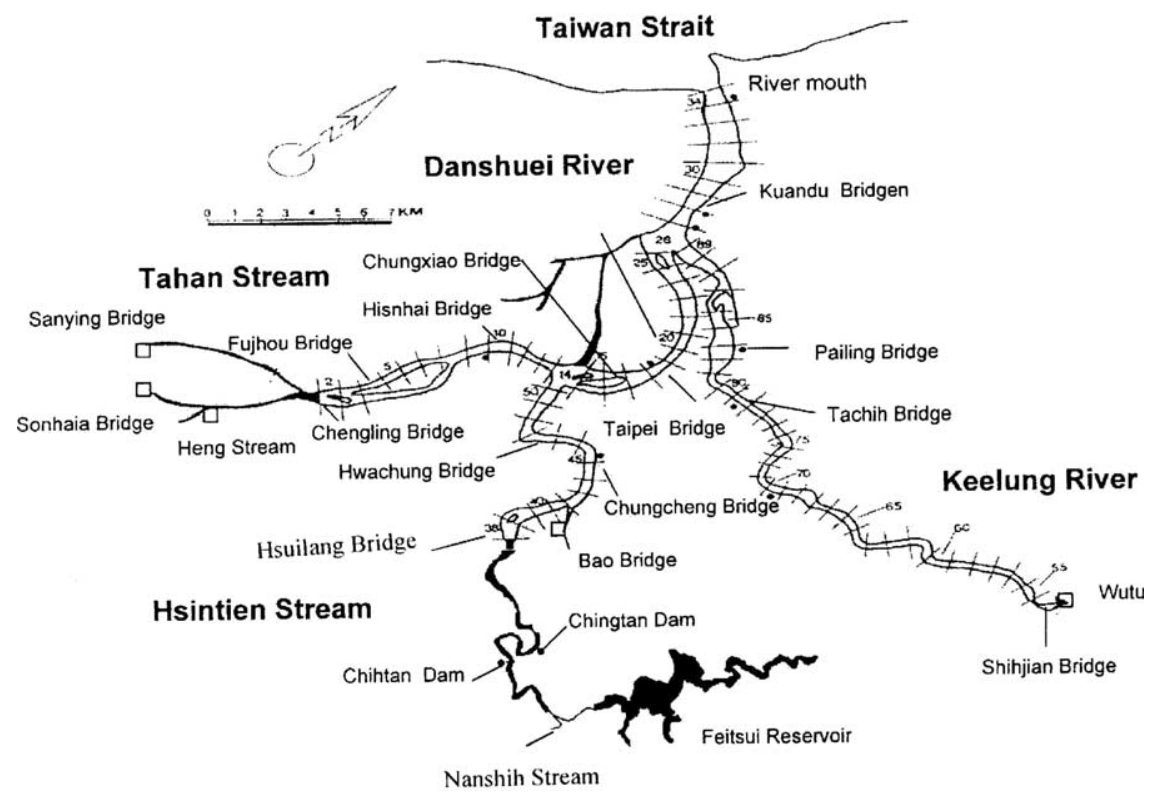

Fig. 3. Map of the Danshuei River estuarine system. 
the estuarine circulation and salinity distribution in the Danshuei River under various hydrological conditions. The results indicate that the Danshuei River system is partially mixed in most instances.

Six million people, over a quarter of Taiwan's entire population, reside in the catchment area of the Danshuei River system. The Danshuei estuary receives both treated and untreated domestic wastewater and industrial effluents. It is heavily polluted by trace metals (Tseng, 1991; Chen and Hung, 1998) and organic materials (Jeng and Han, 1994). The upper estuary is suboxic and gradually becomes oxic in the lower estuary where the seawater dilution improves the water quality (Chen and Hung, 1998).

The Feitsui Reservoir, Chingtan Dam and Chihtan Dam are located at the upriver reach of the Hsintien Stream. They impound the freshwater and divert it for municipal water supply. During low-flow periods the instream flow becomes minimal and the dissolved oxygen declines. Fish kills happen from time to time in the Hsintien Stream and it is desirable to find ways to mitigate the problems.

The model segments are also shown in Fig. 3. The geometry in the vertical two-dimensional model is represented by the width at each layer at the center of each segment (grid cell). A field survey in 2000 by the Water Resources Agency, Taiwan collected the cross-sectional profiles about every $0.5 \mathrm{~km}$ along the tidal portion of the river. For modeling purposes, the Tahan Stream-Danshuei River is regarded as the mainstream of the river, while the Hsintien Stream and Keelung River are treated as the first and second branches, respectively. The river system is divided into 33, 14 and 37 segments, respectively, with a uniform segment length of $1.0 \mathrm{~km}$, which is deemed sufficient for adequate resolution of longitudinal gradient. A smaller segment length would have unnecessarily increased the segment numbers and decreased the computational time step. The model area is bounded by Chengling Bridge on the Tahan Stream, Hsuilang Bridge on the Hsintien Stream, and Wutu station on the Keelung River. The river geometry is schematized with the prototype conditions of the year 2000. The vertical grid spacing is $1 \mathrm{~m}$ for all layers, except the surface layer which is variable with $2 \mathrm{~m}$ at mean sea level. This is to avoid the negative layer thickness at low tide when the water surface may drop to $1.5 \mathrm{~m}$ below mean sea level at spring tide. To determine the model geometry, first the bottom elevation is determined at an integral number of meters below mean sea level. Then the width at each layer is determined while maintaining the cross-sectional area roughly the same as the measured profiles.

\section{Model calibration and verification}

Before reliable simulation can be undertaken for management planning, a water quality model needs to be calibrated and verified with respect to the prototype conditions of the water body to which it is applied. The model has been calibrated and verified with respect to the prototype data from 1994 to 1995 for the Danshuei River system (Liu, 1998; Hsu et al., 1999). The model is further recalibrated for this study using the prototype data from 2000 collected by Taiwan EPA.

\subsection{Hydrodynamic modeling}

In this study, the model is recalibrated with the prototype conditions of year 2000 because there have been significant changes in river geometry since $1995 . \mathrm{M}_{2}$ tide is used for the preliminary recalibration; Manning's friction coefficient is adjusted slightly to reproduce the longitudinal distribution of mean tidal range. Table 1 shows the comparison between the computed and measured mean tidal ranges, the relative errors are less than $1.5 \%$ for all stations.

A 1-year real-time simulation of the year 2000 is conducted for model recalibration. Daily freshwater discharges are specified as the upstream boundary conditions at the three major tributaries, while hourly tidal heights are derived from field data at the river mouth for the downstream boundary conditions. The time step $\Delta t$ is limited by the Courant-Fredrick-Levy stability condition $\Delta t \leq \Delta x / \sqrt{g h}$. A time step increment $(\Delta t)$ of $60 \mathrm{~s}$, which guaranteed stability, was used for hydrodynamic and water quality computations.

The model results compare satisfactorily with observations of water surface elevation and velocity at various stations. Table 2 lists the root-mean-square (RMS) and the relative RMS differences between the computed and measured velocities on May 5, 2000. The time-series

Table 1

Computed and measured average tidal ranges at selected stations

\begin{tabular}{|c|c|c|c|c|c|c|}
\hline \multirow{2}{*}{$\frac{\text { River system }}{\text { Stations }}$} & \multicolumn{4}{|c|}{ Tahan Stream-Danshuei River } & \multirow{2}{*}{$\begin{array}{l}\text { Hsintien Stream } \\
\begin{array}{l}\text { Chungcheng } \\
\text { Bridge }\end{array}\end{array}$} & \multirow{2}{*}{$\frac{\text { Keelung River }}{\text { Tachih Bridge }}$} \\
\hline & River mouth & Tutikungpi & Taiperi Bridge & Hsinhai Bridge & & \\
\hline $\begin{array}{l}\text { Measured tidal } \\
\text { range }(\mathrm{cm})\end{array}$ & 216.3 & 213.5 & 219.8 & 212.8 & 219.4 & 221.4 \\
\hline $\begin{array}{l}\text { Computed tidal } \\
\text { range }(\mathrm{cm})\end{array}$ & 216.3 & 214.2 & 222.8 & 214.2 & 219.0 & 222.1 \\
\hline $\begin{array}{l}\text { Relative difference } \\
(\%)\end{array}$ & 0.0 & 0.3 & 1.3 & 0.6 & 0.2 & 0.3 \\
\hline
\end{tabular}


Table 2

Root-mean-square (RMS) and relative RMS differences between the computed and measured velocities

\begin{tabular}{|c|c|c|c|c|c|}
\hline & Hsinhai Bridge $^{a}$ & Taipei Bridge & Kuandu Bridge & Chungcheng Bridge & Paling Bridge \\
\hline $\begin{array}{l}\operatorname{RMS}_{\text {diff }}(\mathrm{cm} / \mathrm{s}), \text { sur- } \\
\text { face layer }\end{array}$ & 3.11 & 5.52 & 2.31 & 2.16 & 3.14 \\
\hline $\begin{array}{l}\mathrm{RMS}_{\text {diff }}(\mathrm{cm} / \mathrm{s}), \text { bot- } \\
\text { tom layer }\end{array}$ & & 4.25 & 1.32 & 1.14 & 2.27 \\
\hline $\begin{array}{l}\text { RMS }(\mathrm{cm} / \mathrm{s}) \text {, surface } \\
\text { layer }\end{array}$ & 63.58 & 42.17 & 70.30 & 55.80 & 52.81 \\
\hline $\begin{array}{l}\text { RMS }(\mathrm{cm} / \mathrm{s}) \text {, bottom } \\
\text { layer }\end{array}$ & & 32.48 & 42.70 & 42.30 & 37.35 \\
\hline $\begin{array}{l}\text { Relative }_{\text {diff }} \text {, surface } \\
\text { layer }\end{array}$ & 0.049 & 0.131 & 0.033 & 0.039 & 0.059 \\
\hline $\begin{array}{l}\text { Relative }_{\text {diff }} \text {, bottom } \\
\text { layer }\end{array}$ & & 0.131 & 0.031 & 0.027 & 0.061 \\
\hline
\end{tabular}

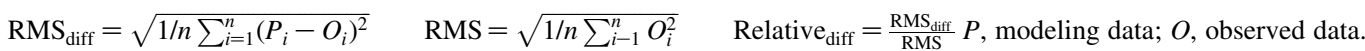

a The depth at Hsinhai Bridge is small, and has only one layer in the model.

comparisons at the Kuandu Bridge and Chungcheng Bridge are shown in Fig. 4 as an example. There are few salinity data for 2000. No calibration with salinity distribution is made; the constants in the turbulence model determined by Hsu et al. (1999) are adopted without recalibration.

\subsection{Water quality modeling}

The recalibration is far more difficult for the water quality model than for the hydrodynamic model, due to the large number of water quality state variables and biochemical reaction coefficients involved. Since the model predictions will change depending upon the selection of the values of biochemical coefficients, consistent coefficient values should be used for different simulation runs. That is, the coefficient values should be transferable for the model predictions to compare with independent sets of field observations.

Field data for water quality variables at various stations have been collected since 1987 by Taiwan EPA. The data include the environmental conditions such as water temperature and downstream boundary conditions. The nonpoint and point source loadings are calculated for the model inputs. The order of the recalibration process is as follows: (1) nonpoint source loadings estimated by regression with river discharge; (2) point source loadings estimated with related references; (3) the field data in the year 2000 are used to compare with model simulation results; (4) adjust the coefficient values preliminarily and fine tune them while comparing the predictions with field observations.

\subsection{Estimation of the nonpoint source loadings}

The water quality model requires the daily loadings of water quality state variables at the upstream boundaries as input data. The drainage basins upstream of tidal limits are much less populated. Therefore, it is assumed that the nonpoint source loadings associated with surface runoff are dominant at the upstream boundaries. The concentrations are related to the river discharge with the exponential function (Hydroscience, 1976)

$C=a Q^{b}$

$W=a Q^{b+1}$

where

$Q \quad$ freshwater discharge in centimeter

$C \quad$ concentration in gram per cubic meter

$W \quad$ loadings in gram per second

$a$ and $b$ empirical constants.

The constants $a$ and $b$ are estimated by regression of the monitoring data of concentrations against the corresponding freshwater discharge on that day. The field data at Fujhou Bridge, Hsuilang Bridge and Shihjian Bridge are taken as the upstream boundaries in the Tahan Stream, Hsintien Stream and Keelung River, respectively. The regression results are listed in Table 3. Some of the regression results are not satisfactory as indicated by low $R^{2}$. This may be due to the insufficient data points and other external factors such as the upstream point source loadings and tidal effects that cannot be accounted for by the magnitude of the river discharge. Nevertheless, all results show correct qualitative trends: ammonium nitrogen, total nitrogen, total phosphorous, and $\mathrm{BOD}_{5}$ are diluted, while $\mathrm{DO}$ increases with increasing discharge. The accuracy of the estimated nonpoint source loadings will significantly affect the model results only at the upriver reaches and only during the high river flow condition. This model application for minimum instream flow determination simulates only the low-flow conditions, therefore the accuracy of nonpoint source loadings has little effect on model results.

The loadings of chlorophyll $a$ are not estimated because this study does not include the effect of chlorophyll $a$. Past studies indicate that there is nearly no phytoplankton in the tidal Hsintien Stream and the upper reach of the Danshuei 

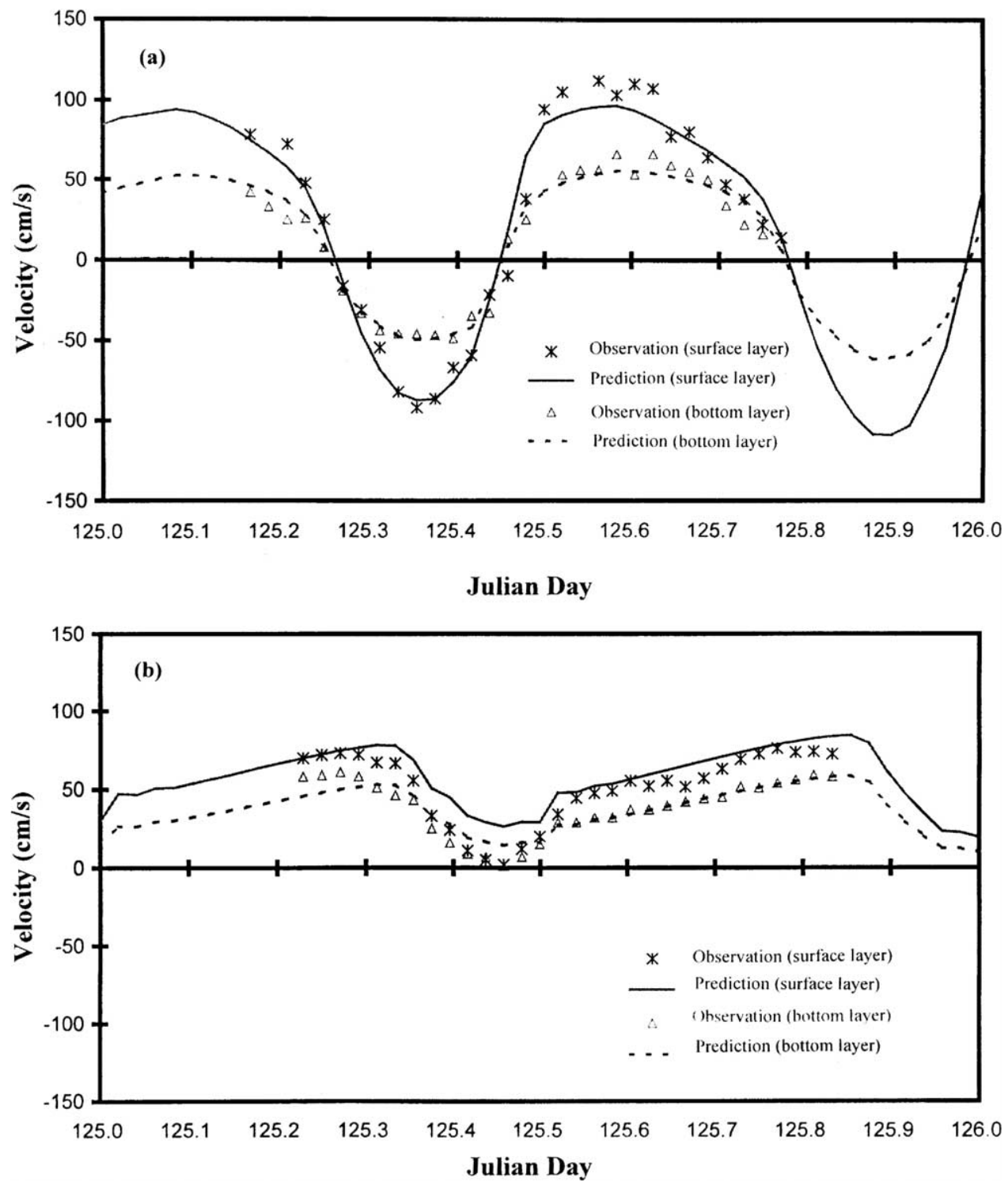

Fig. 4. Computed and measured velocities at (a) Kuandu Bridge and (b) Chungcheng Bridge stations on May 5, 2000.

River estuary. The nonpoint source loadings below the tidal limits are estimated assuming they are proportional to the catchment area of each model segment, and they are directly input into the specific model segments.

\subsection{Estimation of the point source loadings}

The magnitudes of point source loadings are estimated from a past report (Sinotech Engineering Co., 1994) and

Table 3

Regression results of water quality variables at upstream boundaries

\begin{tabular}{llccrrr}
\hline Station & Parameter & $\begin{array}{l}\text { Ammonium nitro- } \\
\text { gen }\end{array}$ & Total nitrogen & Total phosphorus & BOD $_{5}$ & Dissolved oxygen \\
\hline Tahan Stream & $a$ & 9.21 & 26.8 & 1.11 & 24.8 & 1.38 \\
(Fujhou Bridge) & $b$ & -0.48 & -0.51 & -0.25 & -0.37 & 0.32 \\
& $R^{2}$ & 0.67 & 0.75 & 0.17 & 1.28 & 0.78 \\
Hsintien Stream & $a$ & 3.03 & 7.51 & -0.52 & -0.45 & 3.42 \\
(Hsuilang Bridge) & $b$ & -0.27 & -0.30 & 0.62 & 0.50 & 0.15 \\
& $R^{2}$ & 0.21 & 3.35 & -0.38 & -0.37 & 0.31 \\
Keelung River & $a$ & 5.16 & -0.10 & 0.28 & 0.42 & 0.12 \\
(Shihjian Bridge) & $b$ & -0.53 & 0.14 & & & 0.71 \\
& $R^{2}$ & 0.65 & & & & \\
\hline
\end{tabular}


literature values (Thomann and Mueller, 1987) because of the limited monitoring data. BOD is usually used as the major representative of pollutant loadings of wastewater with low-degree or no treatment. Sewage discharge rate, BOD concentration, and the rate at which effluent flow reaches the river were calculated by Sinotech Engineering Consultants, Inc. (1994) in an effort to quantify the pollutant loadings of the Danshuei
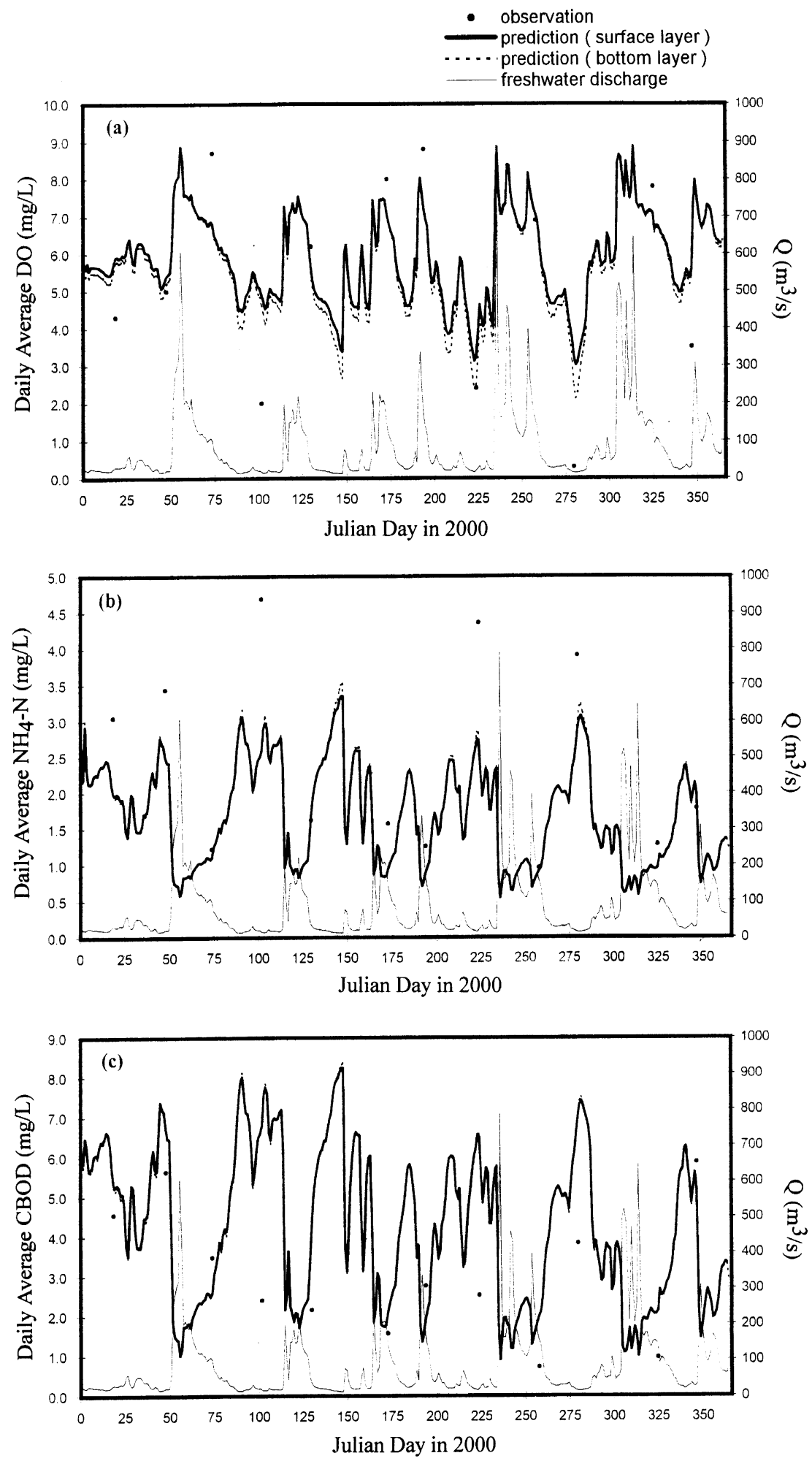

Fig. 5. The comparison of model predictions and field observations at the Chungcheng Bridge station (Hsintien Stream) (a) DO, (b) Ammonium-nitrogen, (c) CBOD. 
River System. The BOD point source loadings were divided into domestic discharge, industrial effluent, livestock discharge, seepage from landfill, and agricultural return flow. The domestic discharge is the dominant pollutant source among all of them. The sewage discharge and BOD loading in the year 2000 and the measured concentrations of ammonium-nitrogen and total phosphorous at several pumping stations are used to estimate the point source loadings and routed to the specific model segments.
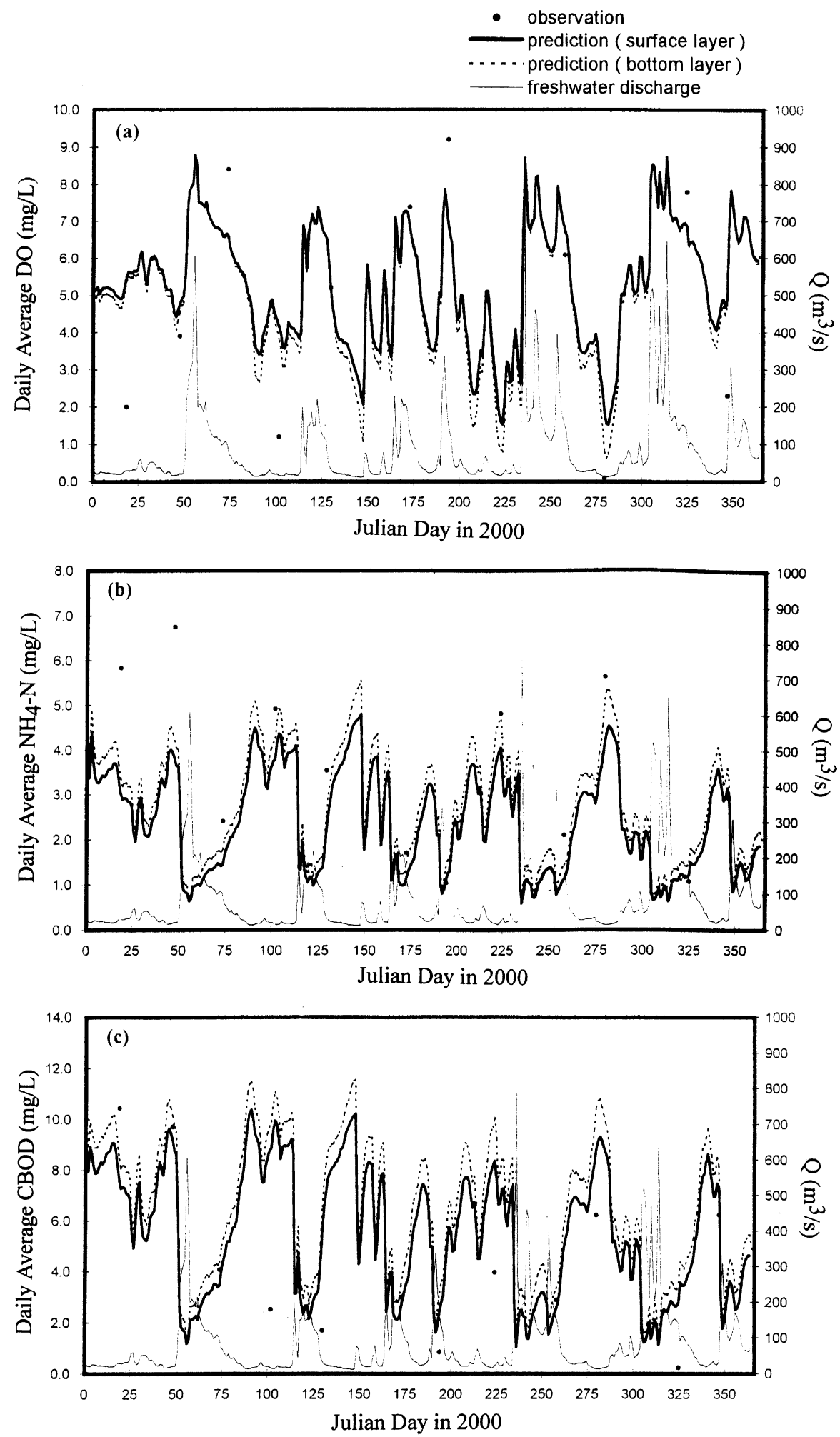

Fig. 6. The comparison of model predictions and field observations at the Hwachung Bridge (Hsintien Stream) (a) DO, (b) Ammonium-nitrogen, (c) CBOD. 


\subsection{Water quality modeling results}

Upstream boundary conditions of the fluxes of the water quality variables are calculated with the regression formula as described above. The average field data measured at the river mouth are used as the downstream boundary condition. Point source loadings are specified with daily constant values as described above. In addition, the temperature affects the water's holding capacity of dissolved oxygen as well as the magnitudes of biochemical coefficients. Daily water temperature in 2000 at Kuandu Station is input to the model.

The model is run for 1-year (366 days) simulation of the year 2000. The model results for daily average concentrations at the surface and bottom layers are compared with the observed values at the corresponding stations under the Hsinhai Bridge, Chungshiao Bridge, Chrongyang Bridge, Kuandu Bridge, Chungcheng Bridge, Hwachung Bridge, Tachih Bridge, and Pailing Bridge. Figs. 5 and 6 present the concentrations of DO, ammonium-nitrogen, and CBOD at the Chungcheng Bridge and Hwachung Bridge, respectively, in the Hsintien Stream. These figures show that the model results and field measurements are generally in good agreement. The temporal variabilities of the model results are generally smaller than those of the field data, because the model results represent the daily average values of the lateral average concentrations while the field data are point measurements, and also because of the random variability inherent to a natural system. The errors averaged over all stations are $0.067,-0.924,0.053,-0.516,-0.188,0.025$, and $0.813 \mathrm{mg} / \mathrm{L}$, respectively, for organic nitrogen, ammonia nitrogen, nitrite-nitrate nitrogen, total nitrogen, total phosphorus, CBOD, and DO. The negative values indicate that the measured data are higher than the model results. The root-mean-square differences for all stations are $0.42,1.76$, $0.37,1.05,0.29,2.81$, and $2.34 \mathrm{mg} / \mathrm{L}$, respectively, for organic nitrogen, ammonia nitrogen, nitrite-nitrate nitrogen, total nitrogen, total phosphorus, CBOD, and DO. Table 4 lists the values of all biochemical reaction coefficients adopted in the model.

\section{Fish kills in the Hsintien stream}

Fish kills have occurred in the Hsintien Stream in recent years, causing a stench and raising concern. Ko et al. (2002) investigated the reasons for fish suffocation when fish kills happened in the Hsintien Stream in 2001 and concluded that the shortage of dissolved oxygen was the main culprit. Wang (2001) and Ko et al. (2002) have also investigated the fish species in the Hsintien Stream. They found that the number of fish species is higher in upriver than in downriver reaches, and Tilapia mossambica, which is more tolerant to pollution, is the dominant species.

Oxygen is essential for fish to survive. Fish kills will occur if oxygen levels drop below a certain critical

Table 4

The biochemical reaction coefficients used in the model

\begin{tabular}{|c|c|}
\hline Coefficient & Value \\
\hline CBOD decay rate at $20^{\circ} \mathrm{C}$ & 0.2 day $^{-1}$ \\
\hline Constant for temperature adjustment of CBOD decay rate & 1.047 \\
\hline Half-saturation concentration for benthic flux of CBOD & $0.5 \mathrm{mg} / \mathrm{L}$ \\
\hline Settling rate of $\mathrm{CBOD}$ & $0.0 \mathrm{~cm} /$ day \\
\hline Sediment oxygen demand & $2.5-4.0 \mathrm{~g} /\left(\mathrm{m}^{2} /\right.$ day $)$ \\
\hline Constant for temperature adjustment of DO aeration rate & 1.024 \\
\hline Ammonification rate at $20^{\circ} \mathrm{C}$ & $0.1 \mathrm{mg} /(\mathrm{L} /$ day $)$ \\
\hline Constant for temperature adjust of ammonification rate & 1.04 \\
\hline Half-saturation concentration for ammonification & $1.0 \mathrm{mg} / \mathrm{L}$ \\
\hline Settling rate of organic nitrogen & $8.0 \mathrm{~cm} /$ day \\
\hline Nitrification rate at $20^{\circ} \mathrm{C}$ & $0.1 \mathrm{mg} /(\mathrm{L} /$ day $)$ \\
\hline Constant for temperature adjustment of nitrification rate & 1.04 \\
\hline Half-saturation concentration for nitrification & $1.0 \mathrm{mg} / \mathrm{L}$ \\
\hline Half-saturation concentration for oxygen limitation of nitrification & $2.0 \mathrm{mg} / \mathrm{L}$ \\
\hline Denitrification rate at $20^{\circ} \mathrm{C}$ & 0.35 day $^{-1}$ \\
\hline Constant for temperature adjustment of denitrification rate & 1.045 \\
\hline Half-saturation concentration for denitrification & $0.5 \mathrm{mg} / \mathrm{L}$ \\
\hline Benthic flux of organic nitrogen & $0.0 \mathrm{~g} /\left(\mathrm{m}^{2} /\right.$ day $)$ \\
\hline Bethic flux of ammonia nitrogen & $0.05 \mathrm{~g} /\left(\mathrm{m}^{2} /\right.$ day $)$ \\
\hline Bethic flux of nitrite-nitrate nitrogen & $0.0 \mathrm{~g} /\left(\mathrm{m}^{2} /\right.$ day $)$ \\
\hline Phosphorus mineralization rate at $20^{\circ} \mathrm{C}$ & $0.06 \mathrm{mg} /(\mathrm{L} /$ day $)$ \\
\hline Constant for temperature adjustment of minerization rate & 1.04 \\
\hline Half-saturation concentration for mineralization & $1.0 \mathrm{mg} / \mathrm{L}$ \\
\hline Settling rate of organic phosphorus & $0.0 \mathrm{~cm} /$ day \\
\hline Settling rate of inorganic phosphorus & $0.0 \mathrm{~cm} /$ day \\
\hline Benthic flux of organic phosphorus & $0.0 \mathrm{~g} /\left(\mathrm{m}^{2} /\right.$ day $)$ \\
\hline Benthic flux of inorganic phosphorus & $0.0-0.005 \mathrm{~g} /\left(\mathrm{m}^{2} /\right.$ day $)$ \\
\hline
\end{tabular}


Table 5

Critical oxygen concentration for common fish species in the Hsintien Stream (Jaw, 1980)

\begin{tabular}{ll}
\hline Species & $\begin{array}{l}\text { Critical oxygen concentration } \\
(\mathrm{mg} / \mathrm{L})\end{array}$ \\
\hline Mugil cephalus & 3.0 \\
Terapon jarbua & 2.0 \\
Gobius similes & 2.0 \\
Tilapia mossambica & 2.0 \\
Cyprinus carpio & 1.2 \\
Anguilla japonica & 1.0 \\
Carassius auratus & 0.7 \\
\hline
\end{tabular}

concentration that depends on the fish species. Table 5 lists the experimental results of Jaw (1980) for the critical oxygen concentrations for some common fish species in the Hsintien Stream. The fish would not die immediately if dissolved oxygen decreases to the critical oxygen level; they still can survive until the dissolved oxygen drops lower to the suffocation point. The minimum dissolved oxygen levels for some common fish are listed in Table 6, which shows that most fish will suffocate if dissolved oxygen is below $1 \mathrm{mg} / \mathrm{L}$.

According to the investigation of fish species and their oxygen demand, the critical oxygen concentration of the dominant species (T. mossambica) in the Hsintien Stream, $2 \mathrm{mg} / \mathrm{L}$, and the minimum dissolved oxygen for avoiding fish kills, $1 \mathrm{mg} / \mathrm{L}$, are chosen for the following model applications. The $1 \mathrm{mg} / \mathrm{L}$ is used as the criterion needed to be maintained at all times. The $2 \mathrm{mg} / \mathrm{L}$ is used for sustaining the fish life cycle and for model sensitivity analyses.

\section{Model applications}

The recalibrated model is used to investigate the water quality conditions under different scenarios and to determine the minimum instream flow in the Hsintien Stream.

\subsection{Sensitivity analyses}

The past fish kills in the Hsintien Stream all occurred during periods of low river flow. The model recalibration results (Figs. 5 and 6) also indicate that low DO occurs while the river flow is low. Therefore, we will attempt to investigate the DO sensitivity to river flow as well as to the reduction of pollutant loadings.

The conditions in 2000 are used as the basis for performing sensitivity analyses. We will focus on the model-predicted DO in the bottom layer at the Hwachung Bridge, which is located near the mouth of the Hsintien Stream. Both the model results and field data indicate that DO increases in the upriver direction from the Hsintien Stream mouth. The DO in the entire river would exceed the criteria if the DO in the bottom layer at the Hwachung Bridge meets the criteria. In the following sensitivity analyses, 1 or $2 \mathrm{mg} / \mathrm{L}$ are used as criteria for comparison.

\subsubsection{Flow augmentation without point source reduction}

Since the capacity of the river to assimilate BOD and pollutants changes with the flow, we evaluate the effect on DO concentration by increasing river flow. Chingtan Dam and Chihtan Dam are located downstream of the Feitsui Reservoir and divert flows for municipal water supply. Fig. 7 shows the flow diversion records at the Chingtan Dam and Chihtan Dam in 2000. The Chingtan Dam and Chihtan Dam took an average of 12.56 and $24.66 \mathrm{~m}^{3} / \mathrm{s}$, respectively. The total diversion constituted about $39 \%$ of the average available flow, which was the sum of flows released from the Feitsui Reservoir and Nanshih Stream in 2000.

A possible scenario is that the Chingtan Dam and Chihtan Dam release additional flow to the Hsintien Stream while nothing is done to reduce the point source loadings. Fig. 8 shows an example of the increase in DO concentration at the Hwachung Bridge if the river discharge is increased by $12.5 \mathrm{~m}^{3} / \mathrm{s}$ throughout the year of 2000 . The results reveal that DO concentration is lower than $2 \mathrm{mg} / \mathrm{L}$ on only 1 day.

\subsubsection{Point source reduction without flow augmentation}

A series of model simulation runs was performed by reducing the point source loadings while maintaining the same river flow for the year 2000. Fig. 9 shows that if the point source loadings are reduced by $50 \%$, the DO concentration in the bottom layer at the Hwachung Bridge station will be higher than $1 \mathrm{mg} / \mathrm{L}$ throughout the whole year. However, it will fail to meet the DO criterion of $2 \mathrm{mg} / \mathrm{L}$, even though the annual average DO concentrations at the surface and bottom layers are 5.47 and $5.27 \mathrm{mg} / \mathrm{L}$, respectively. If the point source loadings are completely

Table 6

Suffocation level of dissolved oxygen concentration for some fishes (Meyer and Barclay, 1990)

\begin{tabular}{ll}
\hline Species & Dissolved oxygen $(\mathrm{mg} / \mathrm{L})$ \\
\hline Lateolabrax japonicus & 0.87 \\
Hypopothalmichthys molitrix & 0.79 \\
Mylopharyngodon piceus & 0.58 \\
Mugil cephalus & 0.50 \\
Ctenopharyngodon idellus & 0.39 \\
Aristichthys nobilis & 0.23 \\
Cyprinus carpio & 0.15 \\
\hline
\end{tabular}




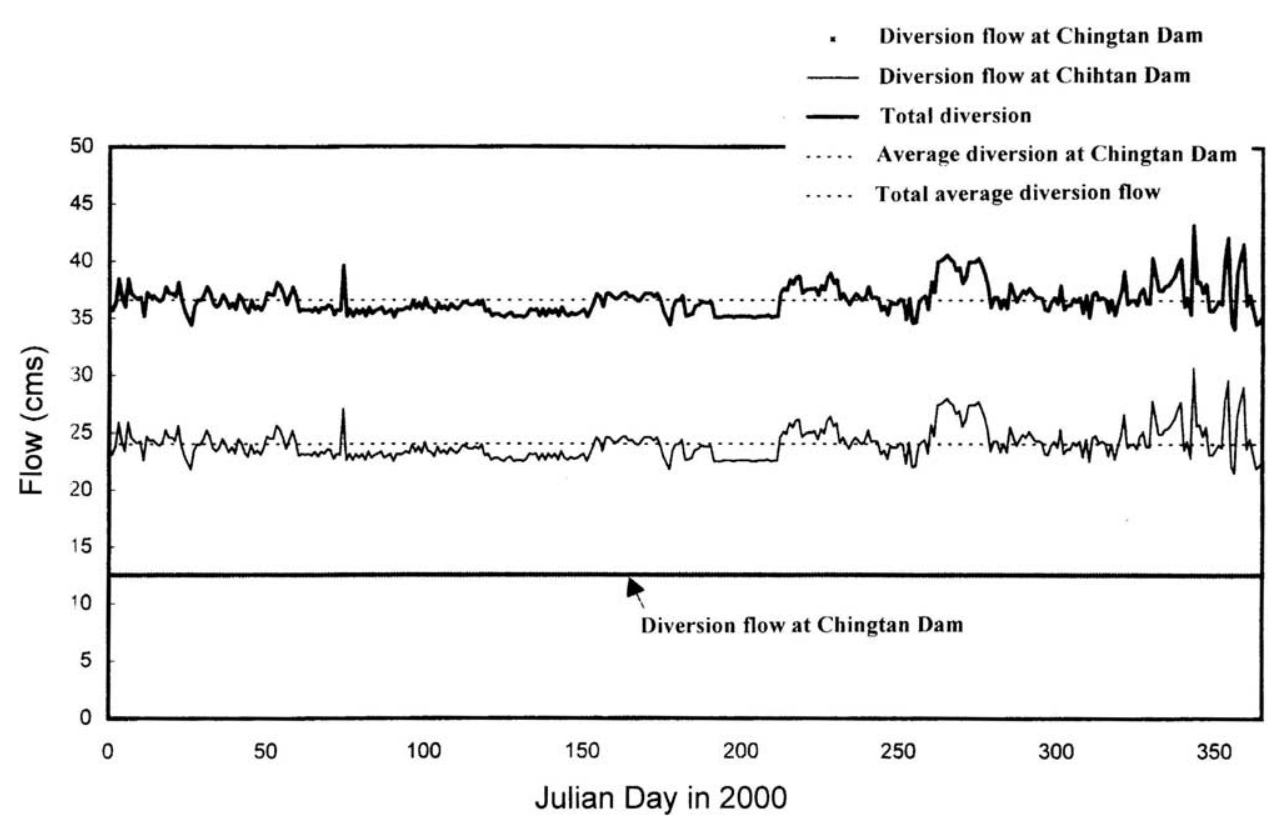

Fig. 7. Flow diversion records at the Chingtan and Chihtan Dams in 2000.

eliminated (Fig. 10), there will still be 3 days in which the DO falls slightly below $2 \mathrm{mg} / \mathrm{L}$.

\subsubsection{Combination of the flow augmentation and point source reduction}

Another series of model runs was conducted with the combination of flow augmentation and point source reduction. Fig. 11 gives an example showing that DO concentration will exceed $2 \mathrm{mg} / \mathrm{L}$ throughout the year when the river flow is increased by $7.5 \mathrm{~m}^{3} / \mathrm{s}$ and point source loadings are reduced by $75 \%$ at the same time.

\subsection{Model simulations for water quality management}

The daily freshwater discharge in the Hsintien Stream during 2000 was higher than in many other years and may not be representative of the danger to fish survival during drought periods. Therefore, a designed flow is used in this study to investigate the critical condition for fish survival. Daily freshwater discharges in the Danshuei River system from 1987 to 2000 are used to compute the $Q_{90}$ and $Q_{75}$ low flow of the month. $Q_{75}\left(Q_{90}\right)$ flow is the flow which is equaled or exceeded $75 \%(90 \%)$ of the days in the month. Both $Q_{75}$ and $Q_{90}$ will be used as the designed low flow in

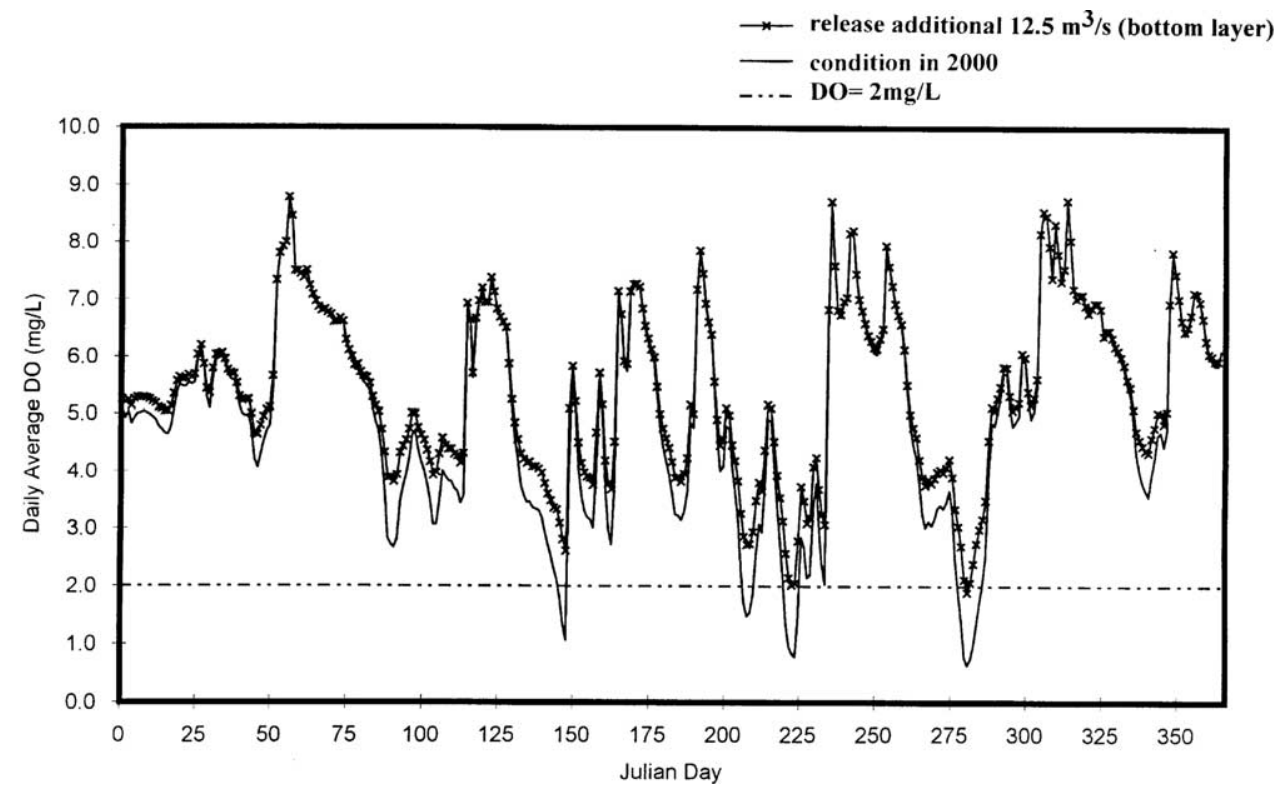

Fig. 8. Model-predicted DO concentration in the bottom layer of Hwachung Bridge if the daily river flow of 2000 in the Hsintien Stream is increased by $12.5 \mathrm{~m}^{3} / \mathrm{s}$. 


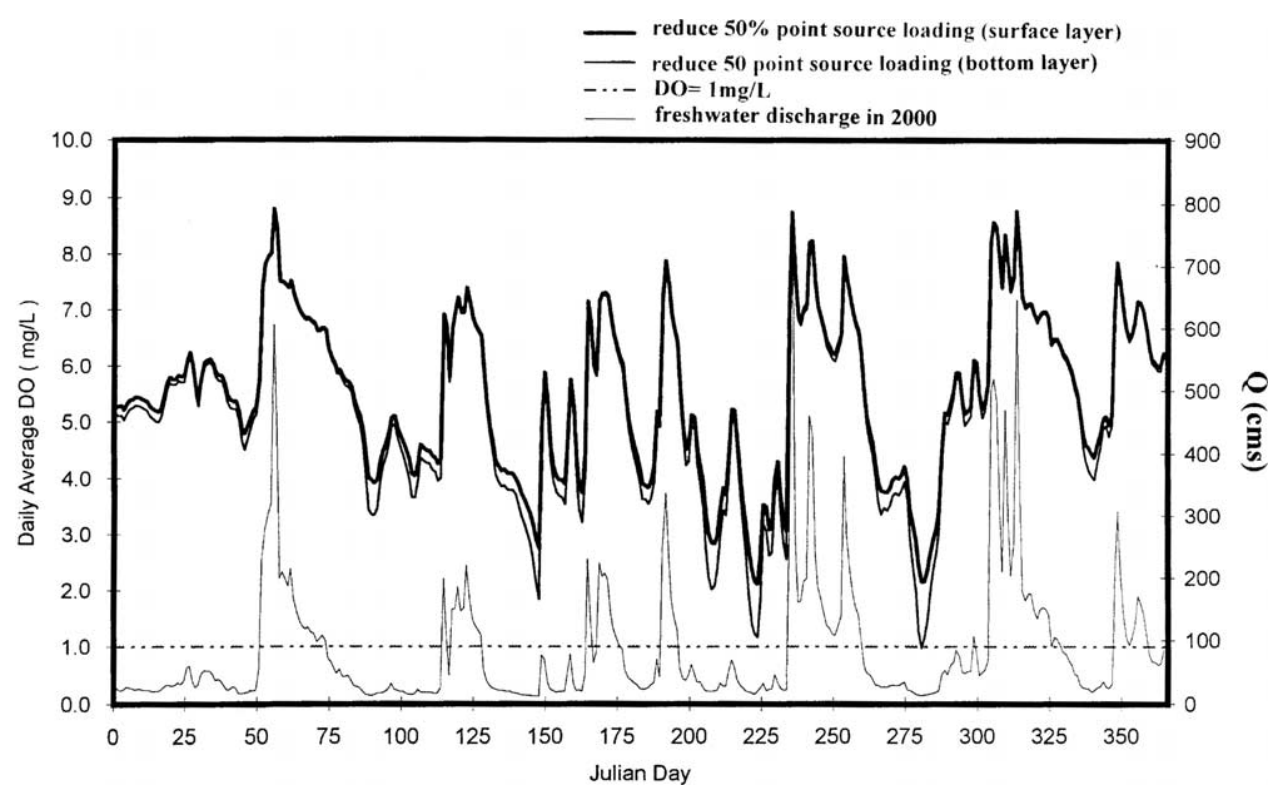

Fig. 9. Model-predicted DO concentration in the surface and bottom layers of Hwachung Bridge if point source loadings are reduced by $50 \%$.

the following application. Water temperature data at the Kuandu Bridge station collected from 1987 to 2000 are used to generate the 90th percentile value of water temperature for each month. Fig. 12 shows the monthly average, maximum, minimum, and the 90th percentile values. The 90th percentile value is used as the temperature for the designed condition, which is exceeded $10 \%$ of the time in the month. These conditions of the designed low flow and high water temperature are anticipated to represent the critical situation for fish survival. Alternative scenarios to improve the water quality will be investigated through model simulation. In the following sections, a DO concentration of $1 \mathrm{mg} / \mathrm{L}$ is used as the water quality criterion.

\subsection{1. $Q_{90}$ as the designed flow}

In this model simulation, the freshwater discharge varies from month to month with $Q_{90}$ flow of the month at each of the three upstream boundaries. Spatially uniform water temperature is assumed, and it also varies monthly using the 90th percentile values. The model results for the DO concentration in the bottom layer at Hwachung Bridge station are presented in Fig. 13. The annual average DO concentration is $1.48 \mathrm{mg} / \mathrm{L}$ and there are 129 days with daily averaged DO concentration lower than $1 \mathrm{mg} / \mathrm{L}$. This imposes a serious threat to fish survival. If the point source loadings are reduced by $90 \%$, the model results (Fig. 13) reveal that the annual average DO concentration increases to $3.40 \mathrm{mg} / \mathrm{L}$ and the daily averaged $\mathrm{DO}$ is lower than

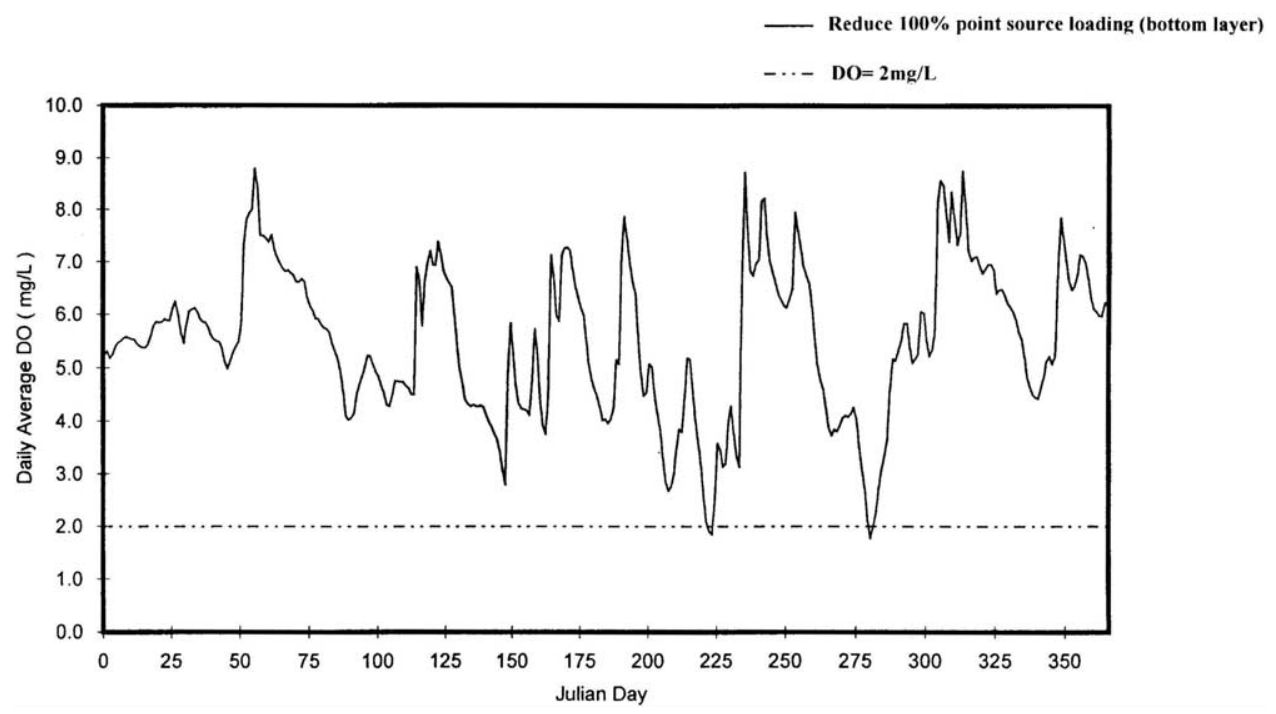

Fig. 10. Model-predicted DO concentration in the bottom layer of Hwachung Bridge if all point source loadings are eliminated. 


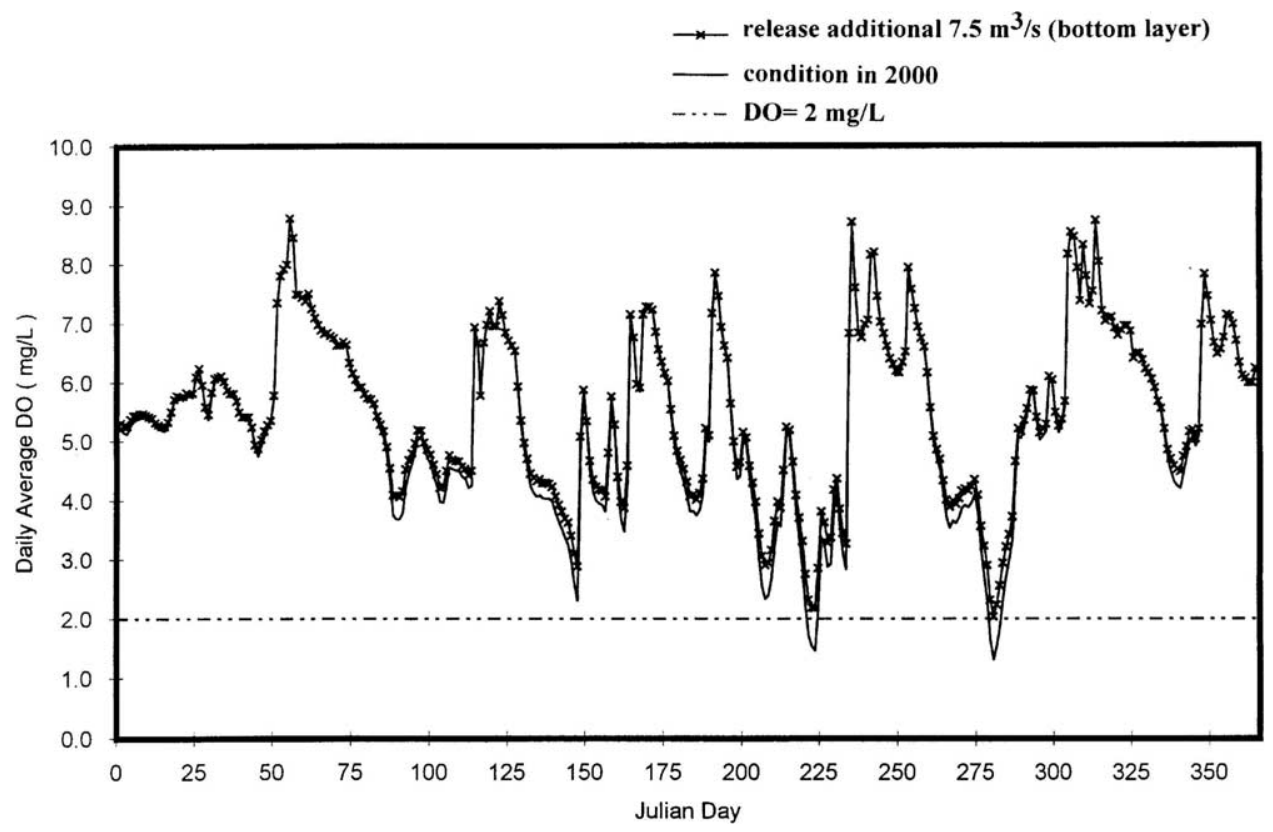

Fig. 11. Model-predicted DO concentration in the bottom layer of Hwachung Bridge if the reservoir and two dams release additional $7.5 \mathrm{~m}^{3} / \mathrm{s}$ and point source loadings are reduced by $75 \%$.

$1 \mathrm{mg} / \mathrm{L}$ for only 1 day of the year. Fig. 13 also demonstrates that there is a fortnightly cycle of DO fluctuation which corresponds to the spring-neap tidal cycle. The variation in dilution by tidal flow becomes more pronounced under the low river flow condition.

\subsection{2. $Q_{75}$ as the designed flow}

Fig. 14 presents the model results if $Q_{75}$ is used as the designed flow. The model results reveal that the annual average DO concentration in the bottom layer at Hwachung Bridge station is higher than the previous case, and reaches $2.40 \mathrm{mg} / \mathrm{L}$. However, there are still 26 days with daily average DO concentration lower than $1 \mathrm{mg} / \mathrm{L}$. If the point source loadings are reduced by $75 \%$, the annual average DO concentration reaches $3.53 \mathrm{mg} / \mathrm{L}$ and the daily averaged DO is higher than $1 \mathrm{mg} / \mathrm{L}$ throughout the year.

\section{Conclusions}

A time-dependent, laterally averaged, two-dimensional hydrodynamic and water quality model is applied to the tidal reach of the Danshuei River system to simulate the dissolved oxygen distribution. The water quality model,

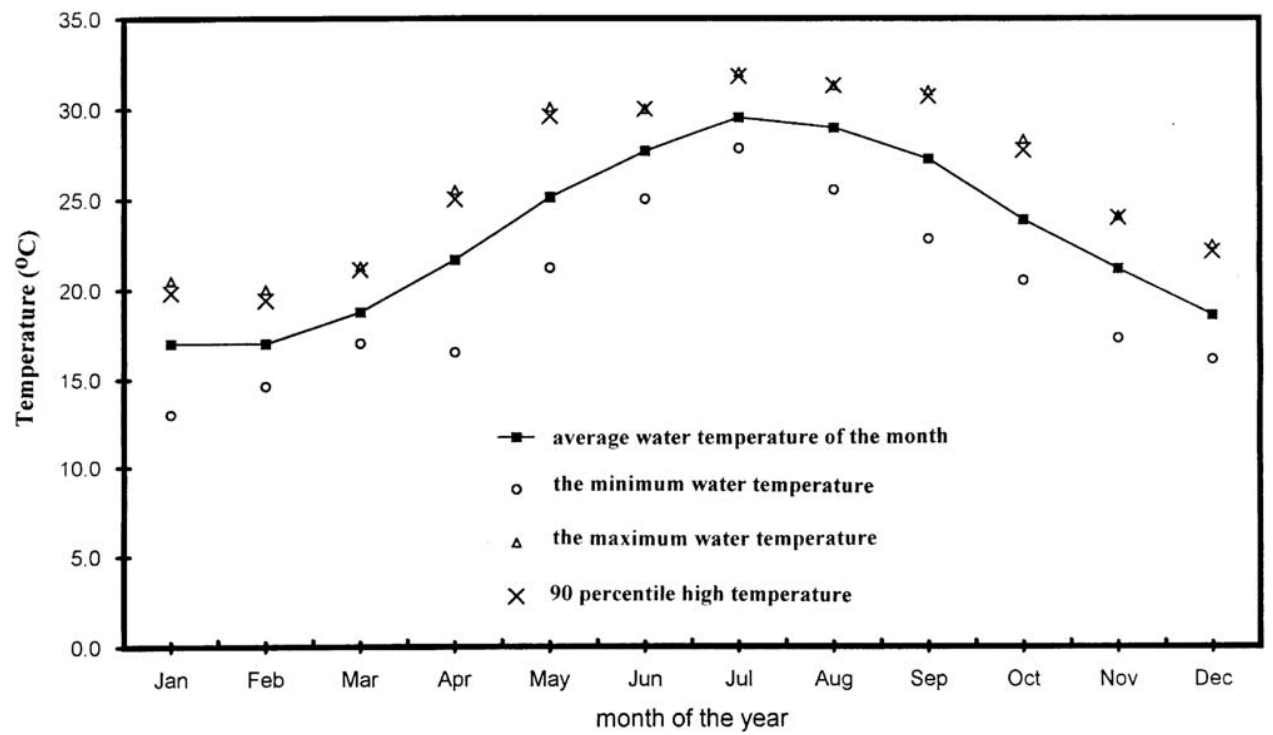

Fig. 12. Average water temperature and the designed temperature for model application, derived from data at the Kuandu Bridge station. 


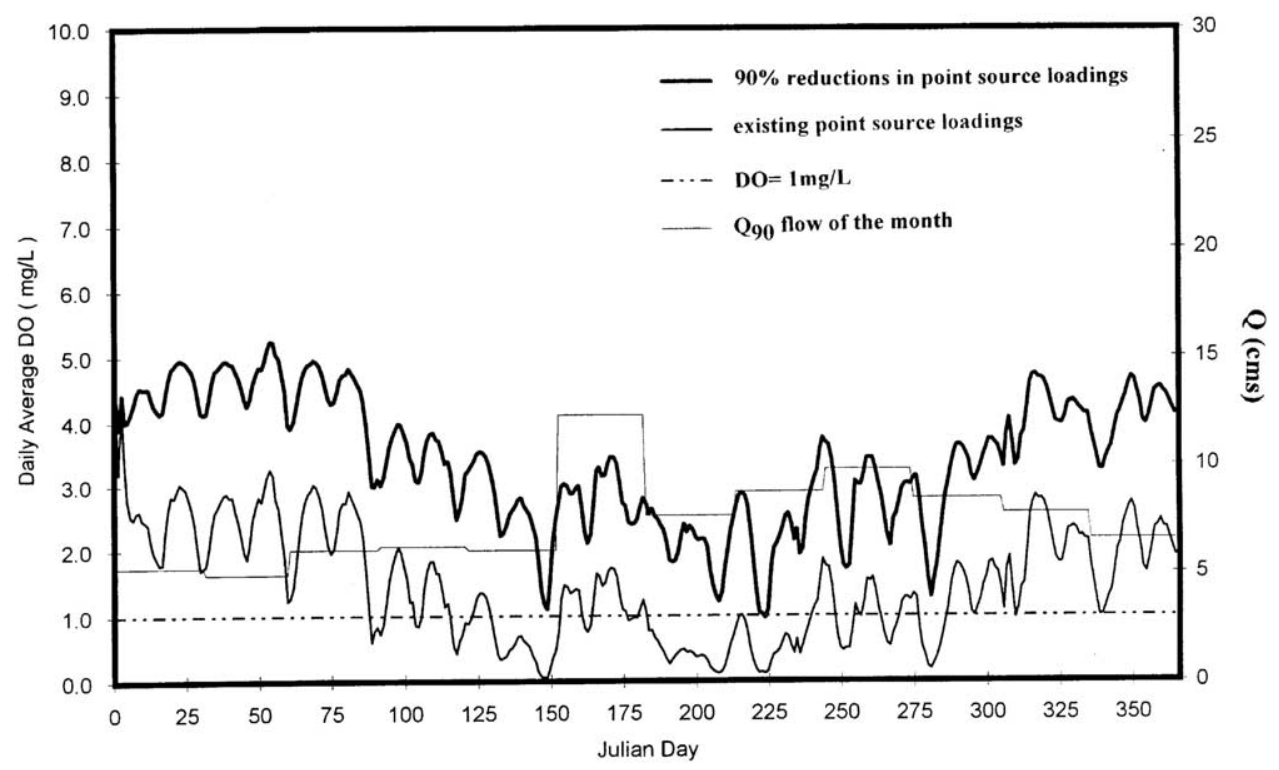

Fig. 13. Model-predicted DO concentration in the bottom layer of Hwachung Bridge under $Q_{90}$ flow condition.

supplied with the information for physical transport processes from the hydrodynamic model, provides realtime predictions of water quality state variables. Hydrodynamic model calibration and verification were conducted with mean tidal range, time varying surface elevation and longitudinal velocity, turbulent mixing, and salinity distribution in the Danshuei River system (Hsu et al., 1999). The model was updated with the geometric data for 2000 and recalibrated with field data for water surface elevation and velocity measured in the same year. The overall performance of the model was in qualitative agreement with field data. The water quality model was also recalibrated using field data collected in 2000. Considering the random variability inherent to natural systems and the goal of consistency in calibrated coefficients, the agreement between the model predictions and field observations is more than satisfactory.

The recalibrated model was used to perform sensitivity analyses. It is demonstrated that the DO concentration in the river is very sensitive to the magnitude of river flow, particularly during the low-flow period. Increasing river flow significantly raises the DO level. The model is then used to simulate various water quality management strategies including river flow management and wastewater loading reduction. Assuming the point source loadings will be reduced by $75 \%$ when the on-going sewer construction project is completed, the maintenance of monthly $Q_{75}$ instream flow will ensure the minimum DO above $1 \mathrm{mg} / \mathrm{L}$

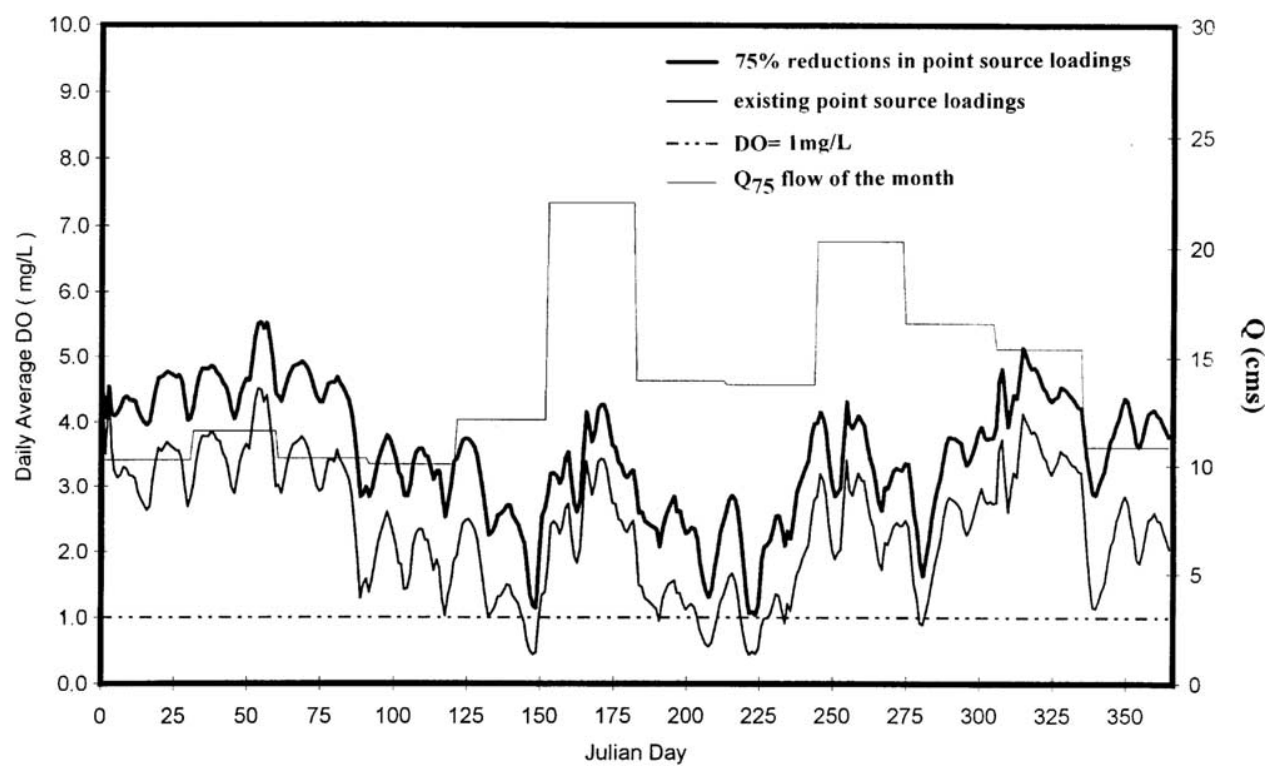

Fig. 14. Model-predicted DO concentration in the bottom layer of Hwachung Bridge under $Q_{75}$ flow condition. 
throughout the year. If a point source reduction of $90 \%$ can be achieved, then the maintenance of $Q_{90}$ instream flow will achieve the same water quality. The Feitsui Reservoir, Chingtan Dam and Chihtan Dam may impound water during the high flow periods and release freshwater to maintain the required instream flow in the Hsintien Stream during the drought periods.

\section{Acknowledgements}

This study was supported, in part, by the Environmental Protection Administration and by the National Science Council (under grant No. NSC 91-2211-E-002-067), Taiwan. The authors would like to thank the Water Resources Agency and Environmental Protection Administration for providing field data.

\section{References}

Banks, R.B., Herrera, F.F., 1977. Effect of wind and rain on surface reaeration. Journal of the Environmental Engineering Division, American Society for Civil Engineer (ASCE) 103 (EE3), 489-504.

Beecher, H.A., 1990. Standards for instream flows. Rivers 1 (2), 97-109.

Bovee, K.D., 1995. A Comprehensive Overview of the Instream Flow Incremental Methodology. National Biological Service, Fort Collins, $\mathrm{CO}$.

Chang, J.C., Shih, T.T., 1991. Sea water intrusion in the Tanshui River. Acta Geologica Taiwanica 29, 163-170.

Chau, K.W., Jin, H.S., 1998. Eutrophication model for a coastal bay in Hong Kong. Journal of Environmental Engineering, ASCE 124 (7), 628-638.

Chen, T.C., Hung, T.C., 1998. The behavior and mobilization of trace metals in the Tanshui River. Journal of the Environmental Protection Society of the Republic of China 11, 21-31.

Hall, R.W., Chapman, R.S., 1985. Two-dimensional QUICKEST; solution of the depth-averaged transport-dispersion equation. Technical Report EL-85-3. US Army Engineer WES, Corps of Engineers, Vicksburg, MS, $29 \mathrm{pp}$.

Harper, D.M., Ferguson, A.J.D., 1995. The Ecological Basis for River Management. Wiley, Chichester, 614 pp.

Hayes, D.F., Labadie, J.W., Sanders, T.G., Brown, J.K., 1998. Enhancing water quality in hydropower system operations. Water Resources Research 34, 471-484.

Hellawell, J.M., 1988. River regulation and nature conservation. Regulated Rivers: Research and Management 2, 425-444.

Herbay, J.P., Smeers, Y., Tyteca, D., 1983. Water quality management with time varying river flow and discharge control. Water Resources Research 19, 1481-1487.

Hsu, M.H., Kuo, A.Y., Liu, W.C., Kuo, J.T., 1997. A study of tidal characteristics, estuarine circulation and salinity distribution in Tanshui River system (II). Technical Report 273. Hydrotech Research Institute, National Taiwan University, Taipei, Taiwan, 146 pp (in Chinese).

Hsu, M.H., Kuo, A.Y., Kuo, J.T., Liu, W.C., 1999. Procedure to calibrate and verify numerical models of estuarine hydrodynamics. Journal of Hydraulic Engineering, ASCE 125 (2), 166-182.

Hydroscience, Inc., 1976. Water quality analysis of Potomac River. Report to the Interstate Commission on Potomac River Basin.
Jaw, G.S., 1980. Studies on oxygen consumption of some aquatic animals. M.S. thesis, College of Chinese Culture, Taipei, Taiwan (in Chinese).

Jeng, W.L., Han, B.C., 1994. Sedimentary coprostanol in Kaohsiung Harbor and the Tanshui estuary, Taiwan. Marine Pollution Bulletin 28, 494-499.

Johnson, B.H., Kim, K.W., Heath, R.H., Butler, H.L., Hsieh, B.B., 1991. User's guide for a three-dimensional numerical hydrodynamic, salinity and temperature model of Chesapeake Bay. Technical Report HL-91-20. US Army Engineer WES, Corps of Engineers, Vicksburg, MS, 41 pp.

Jowett, I.G., 1997. Instream flow methods: a comparison approaches. Regulated Rivers: Research and Management 13, 115-127.

King, J., Tharme, R., Brown, C., 2001. Definition and Implementation of Instream Flows, Contributing Paper for Dams, Ecosystem Functions and Environmental Restoration 2001, http://www.dams.org.

Ko, C.H., Cheng, H.C., Wang, Y.S., Fan, C.H., Liu, W.C., 2002. Water quality and discharge management for fish survival in Hsintien Stream. Environmental Protection Administration Report, Taiwan, EPA-91G107-02-102 (in Chinese).

Lamb, B.L., Doerksem, H.R., 1987. Instream water use in the United States-water laws and methods for determining flow requirements. In National Water Summary, Water Supply Paper 2350. US Geological Survey, Washington, DC, pp. 109-116.

Leonard, B.P., Vachtsevanos, G.J., Abood, K.A., 1978. Unsteady-state, two-dimensional salinity intrusion model for an estuary. In: Brebbia, C. (Ed.), Applied Numerical Modelling. Pen Tech. Press, pp. 113-123.

Liu, W.C., 1998. Modeling study on dynamic transport of hydrodynamic and water quality in tidal estuarine system. PhD Thesis, Graduate Institute of Agriculture Engineering. National Taiwan University, Taipei, Taiwan (in Chinese).

Lung, W., Martin, J.L., McCutcheon, S.C., 1993. Eutrophication analysis of embayments in Prince William Sound, Alaska. Journal of Environmental Engineering, ASCE 119 (5), 811-824.

Maddock, I.P., 1999. The importance of physical habitat assessment for evaluating river health. Freshwater Biology 41, 373-391.

Meyer, F.P., Barclay, L.A., 1990. Field manual for the investigation of fish kills. U.S. Fish and wildlife service, 120pp.

Park, K., Kuo, A.Y., 1993. A Vertical Two-dimensional Model of Estuarine Hydrodynamics and Water Quality, Spec. Rep. App. Mar. Sci. and Ocean Eng. 321. Virginia Institute of Marine Science, Gloucester Point, VA, $47 \mathrm{pp}$.

Park, K., Kuo, A.Y., 1996. A numerical model study of hypoxia in the tidal Rappahannock river of Chesapeake Bay. Estuarine, Coastal and Shelf Science 42 (5), 563-581.

Petts, G.E., 1984. Impounded Rivers. Wiley, Chichester.

Pritchard, D.W., 1954. A study of salt balance in a coastal plain estuary. Journal of Marine Research 13 (1), 133-144.

Pritchard, D.W., 1956. The dynamic structure of a coastal plain estuary. Journal of Marine Research 15 (1), 33-42.

Reiser, D., Wesche, T.A., Estes, C., 1989. Status of instream flow legislation and practices in North America. Fisheries 14 (2), 22-29.

Roache, P.J., 1972. Computational Fluid Dynamics. Hermosa Publisher. 434 pp.

Sinotech Engineering Consultants, Inc., 1994. Inspection on the implementing projects for Danshuei River water quality improvement. Report to Taiwan EPA (in Chinese).

Thatcher, M.L., Harleman, D.R.F., 1972. A mathematical model for the prediction of unsteady salinity intrusion in estuaries. Report No. 72-7, MIT, MA, $232 \mathrm{pp}$.

Thomann, R.V., Mueller, J.A., 1987. Principles of Surface Water Quality Modeling and Control. Harper Collins Publishers, New York.

Tseng, C.M., 1991. Study on speciation of trace metals in sediments. MS Thesis. National Taiwan University, Taipei, Taiwan (in Chinese).

Wang, H.C. 2001. A research of water quality index for fish in Taiwan. Environmental Analysis Laboratory Report (in Chinese). 